\title{
Stem Cells and the Bird Cochlea-Where Is Everybody?
}

\author{
Amanda S. Janesick ${ }^{1,2}$ and Stefan Heller ${ }^{1,2}$ \\ ${ }^{1}$ Department of Otolaryngology-Head and Neck Surgery, Stanford University School of Medicine, Stanford, \\ California 94315 \\ ${ }^{2}$ Institute of Stem Cell Biology and Regenerative Medicine, Stanford University School of Medicine, Stanford, \\ California 94315 \\ Correspondence: janesick@stanford.edu; hellers@stanford.edu
}

\begin{abstract}
In sharp contrast to the adult mammalian cochlea, which lacks regenerative ability, the mature avian cochlea, or basilar papilla (BP) is capable of complete recovery from hearing loss after damage. Avian sensory hair cell regeneration relies on rousing quiescent supporting cells to proliferate or transdifferentiate after hair cell death. Unlike mammalian cochlear supporting cells, which have clearly defined subtypes, avian BP supporting cells are deceptively indistinguishable and molecular markers have yet to be identified. Despite the importance of supporting cells as the putative stem cells in avian regeneration, it is unknown whether all supporting cells possess equal capability to give rise to a hair cell or if a specialized subpopulation exists. In this perspective, we reinvigorate the concept of a stem cell in the $\mathrm{BP}$, and form comparisons to other regenerating tissues that show cell-cycle reentry after damage. Special emphasis is given to the structure of the BP and how anatomy informs both the potential, intrinsic heterogeneity of the supporting cell layer as well as the choice between mitotic and nonmitotic regenerative strategies.
\end{abstract}

\section{HOW THE AVIAN COCHLEA BECAME A MODEL FOR HAIR CELL REGENERATION}

The concept of hair cell regeneration in the nonmammalian cochlea came late to the party with respect to other nonmammalian regenerative models (e.g., amphibian tail, lens, or limb regeneration). This tardiness is largely the result of the lack of accessibility of hearing organs, contributing to technical difficulty in both dissection and manipulation. Traumatizing cochlear hair cells with aminoglycoside antibiotics or loud noise exposure was first shown in the 1940s and 1950s. Acoustic trauma was found to damage the guinea pig organ of Corti (Lurie et al. 1944) and streptomycin was shown to be ototoxic in felines (Hawkins and Lurie 1952). Damage paradigms became useful in identifying intrinsic properties of specific hair cell subtypes like, for example, those of the outer hair cells that were revealed following their death induced by kanamycin in the base of the guinea pig cochlea (Dallos et al. 1972). Furthermore, researchers were able to assess whether recordings from sensory ganglia in a specific tonotopic location were altered when the corresponding

Editors: Guy P. Richardson and Christine Petit

Additional Perspectives on Function and Dysfunction of the Cochlea available at www.perspectivesinmedicine.org

Copyright (C) 2019 Cold Spring Harbor Laboratory Press; all rights reserved; doi: 10.1101/cshperspect.a033183

Cite this article as Cold Spring Harb Perspect Med 2019;9:a033183 
hair cells were damaged (Robertson and Johnstone 1979).

The avian hearing organ, the basilar papilla (BP), was initially not appreciated as a suitable comparative model for the mammalian organ of Corti. Early anatomical papers described the avian $\mathrm{BP}$ as an unorganized, homogenous mass of cells (Retzius 1884; Held 1926). Furthermore, the nucleus isthmi of birds, which projects to the visual system, was believed to be the auditory center, resulting in years of frustrating attempts to construct homology with the mammalian cochlear nucleus (Boord 1969). Because of this apparent lack of evolutionary conservation, it is plausible that the avian auditory system was deemed too archaic for comparative studies. This all changed when ultrastructural imaging showed that the avian cochlea was indeed quite similar to the mammalian organ of Corti, containing short and tall hair cells, corresponding to mammalian outer and inner hair cells, respectively, and resemblances in innervation patterns (Vinnikov et al. 1965; Boord 1969; Rosenhall 1971; Takasaka and Smith 1971). Once accepted as a homologous hearing organ (reviewed in Basch et al. 2016), the BP was further championed to have advantages much akin to the early avian embryo itself-morphological linearity. That is, the avian cochlea, being uncoiled, is more amenable to reconstruction by serial sectioning, compared with the spiraled mammalian organ of Corti (Rubel and Ryals 1982).

Initial experiments leveraging an acoustical damage paradigm led to the demonstration that birds could regenerate lost hair cells, resulting in functional recovery of hearing. Here, the focus was tonotopy, whereby researchers applied a pure tone noise exposure at various frequencies to assess the vulnerability of hair cells to various frequencies from the apex (distal end) to the base (proximal end) of the BP, allowing conclusions to be made about their inherent tuning (Rubel and Ryals 1982; Lippe and Rubel 1983). In the wake of these studies, the occurrence of new hair cells with small hair bundles in soundlesioned areas was reported (Cotanche 1987). Tritium-labeled $\left(\mathrm{H}^{3}\right)$ thymidine and autoradiography was subsequently used to show the mitotic production of new hair cells in the BP after acoustic trauma (Corwin and Cotanche 1988; Ryals and Rubel 1988). The ramifications of these findings for the field were particularly exciting because they inspired a long-lasting (and still-continuing) quest to find biological cures for hearing loss (reviewed in Rubel et al. 2013).

\section{MITOTIC AND NONMITOTIC REGENERATION IN THE AVIAN COCHLEA}

The cellular organization of the chicken BP sensory epithelium becomes evident in cross sections of the cochlear duct (Fig. 1). Clearly visible is a neural-to-abneural gradient of distinct hair cell morphologies and innervation (Fischer et al. 1992). For the purpose of this discussion, we will refer to "neural" and "abneural" as distinct segments of the sensory epithelium where tall and short hair cells are located, respectively (Fig. 1B). Supporting cells belonging to the neural segment show rounder and sparsely packed nuclei compared with those in the abneural segment where the supporting cell nuclei are oval and more tightly packed (Figs. 1B and $2 \mathrm{~A}$ ). The ratio of supporting cells to hair cells on the abneural side is also much higher (Fig. 2B), as previously reported for embryonic stages (Goodyear and Richardson 1997). These differences are, in part, constrained by the larger volume of the sensory epithelium in the neural segment, in which cells can "spread out" from the basement membrane to the apical surface. Whether all supporting cells span the entire distance of the epithelium to surround hair cells apically has not been determined because demarcating supporting cell plasma membranes in the BP have posed technical challenges. Also noticeable is a group of supporting cells whose nuclei line up like "pearls on a string" along the basement membrane juxtaposed to the habenula perforata on the neural limbus; these cells appear distinctively different based on the ordered arrangement of their nuclei (Fig. 1B).

The observed robust regeneration of hair cells prompted the conclusion that the chicken BP harbors somatic stem cells (Corwin and Cotanche 1988; Ryals and Rubel 1988). Circumstantial evidence suggests that hair cell regeneration in the BP indeed is a stem cell-driven 

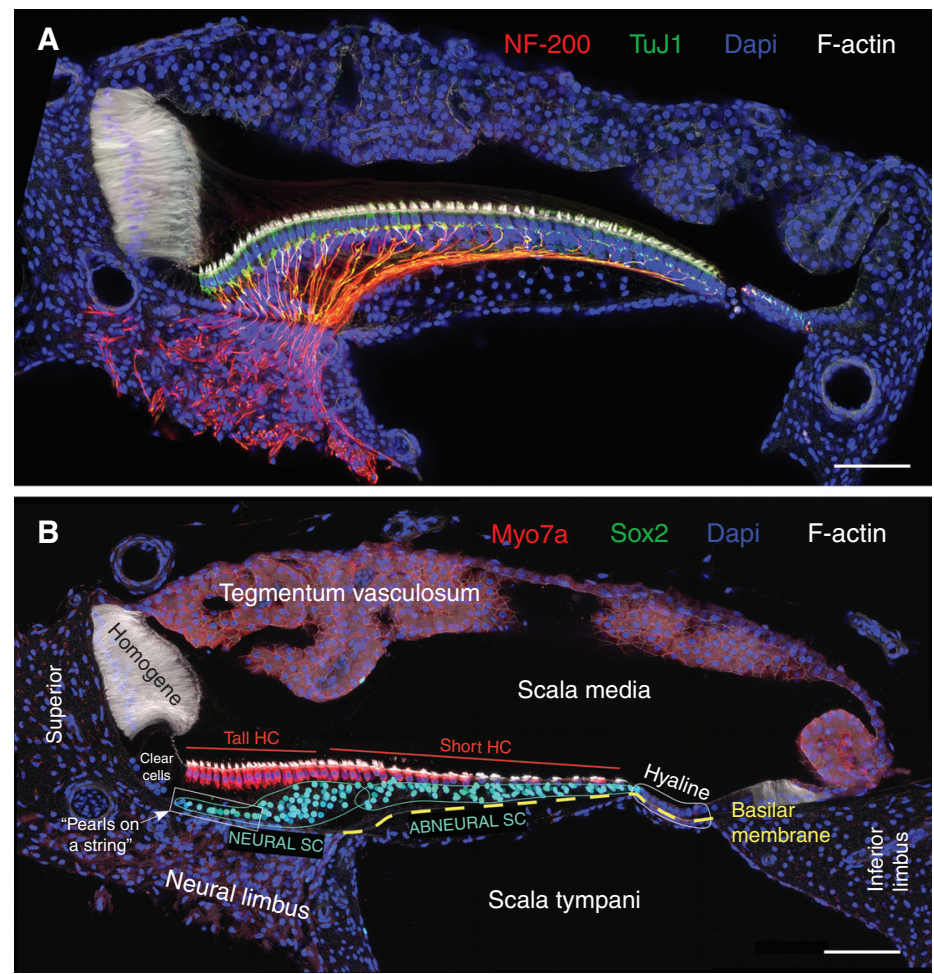

Figure 1. Cross-sectional anatomy of the chicken basilar papilla (BP). Shown are transverse vibratome sections taken from the middle tonotopic region of the chicken BP, roughly equidistant from proximal and distal ends. Embryonic day $20(A)$ and posthatch day $8(B)$ were immunostained for $(A)$ neurofilament-200 (NF-200, Sigma) and tubulin $\beta$ III (TuJ1, EMD Millipore) or (B) myosin-VIIa (Myo7a, Proteus) and Sox2 (Santa Cruz Biotech). Phalloidin labels filamentous (F)-actin and Dapi stains nuclei. Sections were imaged with a Zeiss LSM880 confocal microscope at $40 \times$ magnification using Zen Black acquisition software. SC, Supporting cell; HC, hair cell. Scale bars, $50 \mu \mathrm{m}$.

process, albeit with an interesting twist: New hair cells can arise from either asymmetrically dividing supporting cells, or via phenotypic conversion (also known as "direct transdifferentiation") from underlying supporting cells (Adler and Raphael 1996; Stone and Rubel 2000; Roberson et al. 2004; Cafaro et al. 2007). The latter process was initially discovered in the frog saccule and was based on the observation of intermediate phenotypes between supporting cells and hair cells (Adler et al. 1997; Steyger et al. 1997); transdifferentiation was later verified with mitotic inhibitors (Baird et al. 1996; Baird et al. 2000). Although mitotic and nonmitotic strategies occur largely in parallel, the abneural region of the BP preferentially engages in nonmitotic, direct transdifferentiation-only about one-third of newly generated abneural hair cells incorporate continuously supplied thymidine analog, bromodeoxyuridine (BrdU) when analyzed at 6 days post-gentamicin (Cafaro et al. 2007). This is compared with threefourths of new hair cells incorporating thymidine analog, 5-ethynyl-2'-deoxyuridine (EdU) on the neural side (Cafaro et al. 2007). Given that the time course of regeneration is on the order of months, these studies still represent only an early snapshot of regeneration, before the full complement of hair cells is restored.

Although relatively more hair cells are regenerated by transdifferentiation in the abneural segment, a corresponding increase in dividing abneural supporting cells is not observed (Cafaro et al. 2007). This leads to the intriguing 

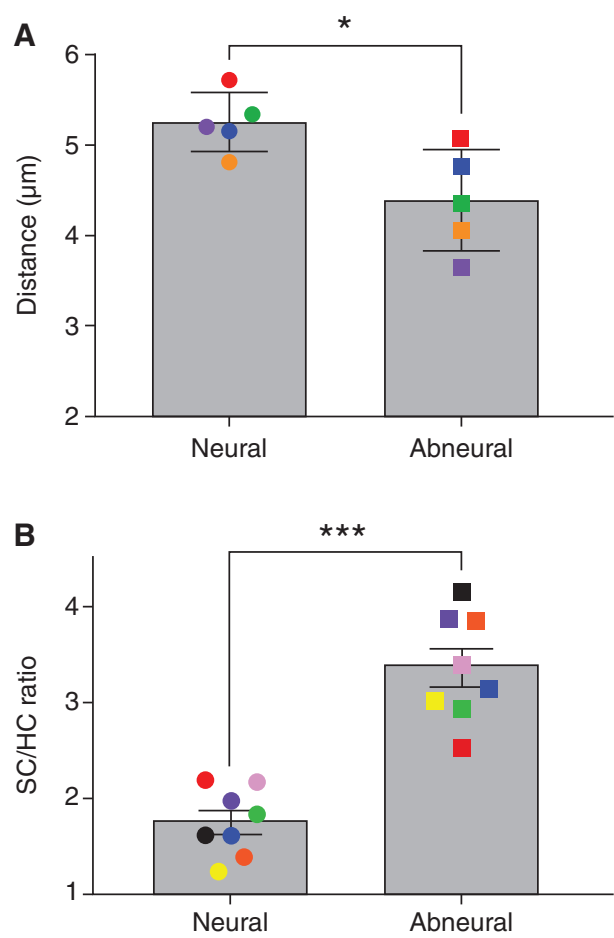

Figure 2. Abneural supporting cells (SCs) in the chicken basilar papilla (BP) are more tightly packed $(A)$ and more numerous than hair cells (HCs) $(B)$ compared with the neural side. Transverse vibratome sections taken from the middle tonotopic region of the chicken BP (posthatch day 8-10) were immunostained for myosin-VIIa (Proteus) and Sox2 (Santa Cruz Biotech). Sections were imaged as in Figure 1. Using syGlass software (see syglass.io), SC and HC nuclei number and location were recorded, standardizing voxel size and Z-depth across sections. Counts and XYZ coordinates were exported. Distance measurements $(A)$ between the nearest neighboring SC nuclei was conducted in MATLAB vR2017b. Data visualization and statistics (paired $t$-test) were performed in GraphPad Prism v7. Each data point of the same color represents one chicken. Error bars, SEM. ${ }^{*} p \leq 0.05,{ }^{* * *} p \leq 0.001$.

question of whether supporting cells are ultimately being replenished. It is conceivable that transdifferentiation happens from a surplus pool of supporting cells, but that the sustainability of this pool might be limited. The tighter packing of supporting cells and increased supporting cell-to-hair-cell ratio on the abneural side (Fig. 2) suggests that perhaps "spare" cells are in reserve for when damage occurs. Supporting cell division might only occur after repeated hair cell loss when cell density decreases below a critical threshold. Alternatively, supporting cells are being replenished but the dynamics of this process are too slow to be unraveled even with long-term infusion of thymidine analogs. Experimental evidence using incorporation of EdU after hair cell loss in the chicken utricle supports the notion that supporting cells that transdifferentiate into new hair cells in vestibular sensory epithelia are being replenished via symmetric supporting cell divisions (Scheibinger et al. 2018). Finally, it is possible that there are new mitotically generated supporting cells migrating into the abneural region from the neural side, but this may only happen when supporting cell density on the abneural side reaches a low threshold. It remains an open question whether supporting cells that transdifferentiate into new hair cells in the abneural segment of the $\mathrm{BP}$ are being replenished in the first place and, if so, by which mechanism.

\section{THE ABSTRACT CONCEPT OF SOMATIC STEM CELLS AND MITOTIC HAIR CELL REGENERATION}

The concept of somatic stem cells that define the regenerative capacity of a particular organ is complex because tissues differ widely in their need for new cells and in their response to injury. For example, the skin or the intestine require sustained cell production as well as rapid regenerative responses. In other tissues, such as the lung, reentry into the cell cycle only occurs in response to damage. Defining specific criteria that unequivocally signify a phenotypic "stem cell" is difficult, and likely irrelevant. Hallmark features of, for example, epidermal, hair follicle, and feather stem cells (Potten and Morris 1988; Cotsarelis et al. 1990; Yue et al. 2005), include self-renewal, label retention (e.g., quiescence), and expression of specific "stem" markers. These criteria have been relaxed based on findings such as the discovery of multiple cell types that show stem cell characteristics within the same tissue such as the intestinal crypt. Here, slow-cycling cells coexist with actively dividing cells (re- 
viewed in Grompe 2012). Such specialized arrangements most likely exist for many adult tissues that require constant production of new cells in the undamaged state as well as the need for a repair response after injury.

The avian BP does not proliferate during normal homeostasis but shows a rapid regenerative response involving S-phase reentry and cell division following hair cell loss or damage (Corwin and Cotanche 1988; Ryals and Rubel 1988; Raphael 1992; Stone and Cotanche 1994; Hashino et al. 1995; Cafaro et al. 2007). Classical label-retaining (e.g., slow-cycling or quiescent) cells have not been reported in this organ, nor has a stem cell niche been identified. One possibility is that many, if not all, supporting cells, rather than a specialized population, are able to reenter the cell cycle to produce new hair cells and new supporting cells. This situation is not unusual as many of the internal organs of the body possess "facultative" stem cells-cells that are ordinarily unipotent and terminally differentiated, but under specific circumstances, such as post-injury, reenter the cell cycle. For example, replenishment of adult $\beta$ cells after partial pancreatectomy proved to be mostly stochastic and each pancreatic cell was found to possess equal capacity to divide (Dor et al. 2004; Teta et al. 2007). Because supporting cells of the chicken BP give an initial impression of homogeneity in which no distinguishing markers have been identified (yet), the stochastic, facultative stem cell as a workhorse of regeneration is a valid hypothesis in the BP.

On the other hand, because different regions in the chicken BP harbor supporting cells with different morphologies (Fig. 1B), one might argue that heterogeneity is observable. Distinct supporting cell types are likely defined or influenced spatially within the BP in specific relation to apical/basal, neural/abneural, and tonotopic location. With respect to stemness, though, it is particularly interesting to consider the environment sensed by supporting cells with "pearls-ona-string" nuclei lined up close to the basement membrane on the neural side of the BP (Fig. 1B). In lung epithelia, signaling from the underlying stromal layer define the $1 \%$ of Wnt-responsive type II alveolar cells that serve as facultative stem cells (Barkauskas et al. 2013; Desai et al. 2014; Ouadah 2018). Much like the supporting cells of the chicken cochlea, type II alveolar cells were once thought to be a homogeneous population with very low turnover. Recently, not only was it found that stem cells constitute only $1 \%$ of type II alveolar cells, but also that they express Axin2, a marker for active Wnt signaling, and are very close in proximity to a Wnt5a-source located in the stromal layer (Ouadah 2018). One could draw an analogy in the chicken; indeed, the group of supporting cells that hug the basement membrane on top of the neural limbus (Fig. 1B) is a potential candidate cell population to receive signals that promote S-phase reentry after damage.

Research to identify factors involved in cellcycle reentry in the avian ear have mainly been conducted with cultured tissue. Although the use of cultured tissue does not preclude the results from being applicable to the in vivo situation, additional experiments are nevertheless required to assess the true significance of the pathways identified. For example, epidermal growth factor receptor (EGFR) signaling has been reported as essential for cell-cycle reentry; insulin and insulin-like growth factor (IGF)-1 as promoting, and fibroblast growth factor (FGF)-2 as inhibitory for cell-cycle reentry in the avian BP (Oesterle et al. 1997, 2000; White et al. 2012). Moreover, WNT signaling, particularly WNT4, as well as transforming growth factor (TGF)- $\beta$ and JUN family transcription factors were identified in a knockdown small interfering RNA (siRNA) screen as being essential for cell proliferation in avian inner ear sensory epithelia. In contrast, inhibition of $\gamma$-secretase or ADAM10 led to increased proliferation, particularly in the utricle (Alvarado et al. 2011; Warchol et al. 2017).

No clear picture has yet emerged about the order of events that ultimately regulate hair cell regeneration, despite large-scale efforts using cultured sensory epithelia and systematic testing for pathways, informed by transcriptomic analyses of regenerating sensory epithelia (Hawkins et al. 2007; Alvarado et al. 2011; Ku et al. 2014). Single-cell trajectory analysis (Durruthy-Durruthy and Heller 2015; Ellwanger et al. 2018) should provide more refined insights into 
solving this challenging problem. Of particular importance will be the identification of triggers that initiate cell-cycle reentry of supporting cells, as well as coordinating mechanisms that ensure a response that neither undershoots nor overshoots cell numbers and ratios. Quantitative assessments of this process in regenerating chicken utricles in vivo suggest that even after considerable hair cell loss, the number of cells in the regenerating sensory epithelium during the dynamic proliferative phase remains well controlled (Scheibinger et al. 2018).

\section{CHOICE BETWEEN TWO REGENERATIVE MODES}

Whether differential "regeneration modes" in the BP are influenced by cell-intrinsic properties of specific supporting cell subtypes or rather by mechanical forces generated by the gross anatomy of the cochlea remains an open question. The recent finding that cell-cycle regulation in the embryonic mouse utricle is limited by the stiffness of the elastic boundary of the tissue, as manipulated in culture (Gnedeva et al. 2017), suggests that radial stiffness of the basilar membrane might similarly limit the capacity of abneural supporting cells to reenter the cell cycle. In the mouse utricle, Hippo controls supporting cell proliferation through signaling mediated by elastic force-dependent Yap nuclear translocation (Gnedeva et al. 2017). Ototoxic injury of the chicken utricle similarly leads to Yap nuclear translocation in supporting cells (Warchol et al. 2018), suggesting that the Hippo pathway is active in the regenerating chicken inner ear.
Anatomically, the neural region of the chicken BP is a natural extension of the neural limbus, whereas the abneural region is located on the free basilar membrane that connects via a group of cells called the hyaline cells to the inferior limbus, or lateral cartilaginous plate (Fig. 1) (Manley 1990). Chicken hyaline cells are efferently innervated (Fig. 3) (Odinokova and Prokof eva 1975; Keppler et al. 1994; Frisancho et al. 1997) and harbor obliquely angled actin filaments in their basal region that are generally radially oriented in a direction toward the abneural edge of the short hair cells (Cotanche et al. 1992). These cells possess smooth muscle myosin and functional muscarinic acetylcholine receptors that stimulate the release of intracellular $\mathrm{Ca}^{2+}$ in response to activation by acetylcholine, which potentially contributes to concave bending of the basilar membrane (Cotanche et al. 1992; Lippe et al. 2002). These specializations support a hypothesis initially raised by Drenckhahn and colleagues (1991) based on similar observations in the caiman cochlea, which suggested that hyaline cells might be contractile and involved in regulating radial tension on the basilar membrane. This tension, in combination with tighter supporting cell packing in the abneural region (Fig. 2A), could preclude nuclear YAP translocation and thereby prevents supporting cells from reentering the cell cycle. The Hippo pathway is, therefore, a reasonable candidate for a signal that suppresses the cell cycle in the abneural region of the BP. Whether the radial force and tension in this region changes after hair cell ejection remains an open question.

Each regenerative mode is likely to exploit distinct molecular mechanisms. If a supporting

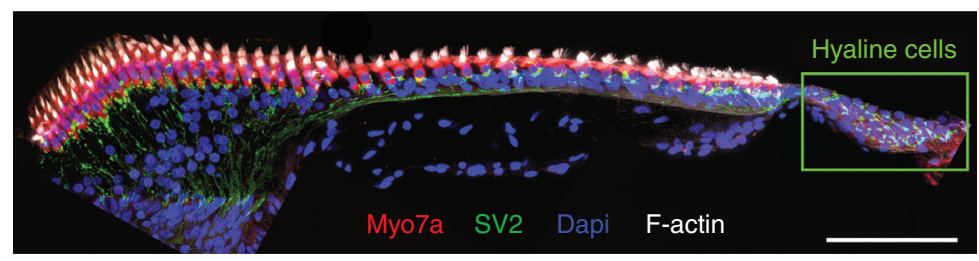

Figure 3. Chicken basilar papilla (BP) hyaline cells are innervated. Shown is a transverse vibratome section taken from the middle tonotopic region of the posthatch day 7 chicken BP immunostained for synaptic vesicles (SV2, Developmental Studies Hybridoma Bank) and myosin-VIIa (Myo7a, Proteus). Phalloidin labels F-actin and Dapi stains nuclei. Sections were imaged as in Figure 1. Scale bar, $50 \mu \mathrm{m}$. 
cell chooses to enter the cell cycle, has it regressed to a more pluripotent state compared with a cell that clandestinely morphed into a hair cell without dividing? As a supporting cell transdifferentiates, does it also regress or effectively "dedifferentiate" or does it transition through an unnatural intermediate to become a hair cell? The appearance of Atoh1, which is essential for hair cell differentiation (Bermingham et al. 1999), is likely to be a major player in a supporting cell's trajectory toward hair cell fate (Ellwanger et al. 2018). However, it is unclear whether the events leading up to Atoh1 expression during regeneration are simply a recapitulation of developmental processes. Discriminating between signaling pathways required for the initial trigger of regeneration that ultimately lead to Sphase reentry or transdifferentiation are likely to be different compared with those used during the normal generation of hair cells. Understanding early responses of supporting cells that are triggered by hair cell loss, as well as classifying latent cellular subtypes, will likely be an important line of experimentation moving forward.

\section{CONCLUDING REMARKS}

Uncovering where stem cells are hiding within the chicken BP will require a progressive viewpoint of what defines a stem cell. As more tissues are studied that defy the classical stem cell paradigm, and as research uses more refined genetic tools, additional features of stem cells emerge. This is particularly relevant in the context of damage/injury whereby cells adopt creative methods for replenishment. The existence of facultative stem cells provides new insight into how seemingly unipotent and terminally differentiated cells are suddenly "reawakened" to reenter the cell cycle under duress. Whether phenotypic conversion (also known as direct transdifferentiation) also relies on a similar rekindling of multipotency or "dedifferentiation" toward developmental origin is an open question. Definitive experimental evidence is needed to clarify which supporting cells in the BP have the ability to undergo mitotic hair cell regeneration. It is currently unresolved whether all supporting cells are able to initiate a regenerative program and are therefore per se facultative somatic stem cells, or whether regeneration can only be performed by specialized and dedicated cochlear stem cells.

To find stem cells, which will assuredly reside within the supporting cell layer, extending beyond hair-cell-centric vantage points (wholemount, top-down imaging) is important. Viewing the cochlea in a transverse section (Fig. 1) provides additional information about supporting cells, revealing cytomorphological heterogeneity that is likely imposed by the greater BP anatomy. Whether descriptive morphological observations correlate with regenerative potential and molecular heterogeneity is unknown. To investigate this relationship, single-cell transcriptomic analysis of the undamaged BP will be useful to identify inherent differences. Nevertheless, transcriptomic variations between supporting cell subpopulations might be difficult to detect if all are poised to respond but require an external signal from the underlying stromal layer or persistent elastic force potentially generated from the hyaline cells. Similarly, supporting cells might change their global epigenetic signature during regeneration rather than altering a specific, genetic pathway. Characterizing the possible reopening of chromatin during regeneration will be an important experimental direction, especially to identify early events. Likewise, it will be crucial to dissect cell-cell signaling at the onset during the progression and at the termination of the distinct regenerative modes. Identification at the cellular level of who is talking to whom, when, and what about is going to be the challenge when applying novel technologies such as single-cell trajectory reconstruction and in situ validation with multiprobe messenger RNA (mRNA)-detection methods (Wang et al. 2012; Nagendran et al. 2018). Ultimately, we argue that, given these technological innovations, the time has come for researchers to unravel the mechanisms of hair cell regeneration in the avian cochlea.

In the neonatal mouse organ of Corti, supporting cells are able to reenter the cell cycle and produce new hair cells in vitro and in vivo (White et al. 2006; Oshima et al. 2007; Sinkkonen et al. 2011; Shi et al. 2012, 2013; Cox et al. 
2014; Li et al. 2015; Wu et al. 2016; McLean et al. 2017). This ability is lost, however, between the second and third postnatal week (White et al. 2006; Oshima et al. 2007). It is debatable whether the regenerative ability of some neonatal supporting cells is reflective of a "rudimentary" stemness or a remnant of developmental capacity that ceases with maturation of the organ of Corti. The crucial question for instigating hair cell regeneration in the mammalian cochlea, however, is whether the regenerative capability of supporting cells is fundamentally lost, irrevocably, in the mature organ of Corti. Or alternatively (and optimistically), the lack of regenerative capacity in mature mammalian cochlear supporting cells is not intrinsic or indelible, and these cells can be engaged in a regenerative program given the proper extrinsic signals. Work that aims to unravel the mechanisms of hair cell regeneration in nonmammalian vertebrates is critical in this respect because it can provide important clues about the sequence of signaling events that orchestrate the regenerative response.

\section{ACKNOWLEDGMENTS}

We thank Dr. Lars Becker and the Stanford Otolaryngology Imaging Core. We also thank Dr. Peter Barr-Gillespie and all members of the Heller laboratory especially Drs. Mirko Scheibinger, Byron Hartman, Daniel Ellwanger, Marie Kubota, Taha Jan, and Giovanni Diaz for their valuable input on the manuscript and inspiring discussion. This emerging work is supported by the Hearing Restoration Project (HRP) consortium funded by the Hearing Health Foundation and by the Stanford Initiative to Cure Hearing Loss.

\section{REFERENCES}

Adler HJ, Raphael Y. 1996. New hair cells arise from supporting cell conversion in the acoustically damaged chick inner ear. Neurosci Lett 205: 17-20.

Adler HJ, Komeda M, Raphael Y. 1997. Further evidence for supporting cell conversion in the damaged avian basilar papilla. Int J Dev Neurosci 15: 375-385.

Alvarado DM, Hawkins RD, Bashiardes S, Veile RA, Ku YC, Powder KE, Spriggs MK, Speck JD, Warchol ME, Lovett
M. 2011. An RNA interference-based screen of transcription factor genes identifies pathways necessary for sensory regeneration in the avian inner ear. J Neurosci 31: 45354543.

Baird RA, Steyger PS, Schuff NR. 1996. Mitotic and nonmitotic hair cell regeneration in the bullfrog vestibular otolith organs. Ann NY Acad Sci 781: 59-70.

Baird RA, Burton MD, Lysakowski A, Fashena DS, Naeger RA. 2000. Hair cell recovery in mitotically blocked cultures of the bullfrog saccule. Proc Natl Acad Sci 97: 11722-11729.

Barkauskas CE, Cronce MJ, Rackley CR, Bowie EJ, Keene DR, Stripp BR, Randell SH, Noble PW, Hogan BL. 2013. Type 2 alveolar cells are stem cells in adult lung. J Clin Invest 123: 3025-3036.

Basch ML, Brown RM II, Jen HI, Groves AK. 2016. Where hearing starts: The development of the mammalian cochlea. J Anat 228: 233-254.

Bermingham NA, Hassan BA, Price SD, Vollrath MA, BenArie N, Eatock RA, Bellen HJ, Lysakowski A, Zoghbi HY. 1999. Math1: An essential gene for the generation of inner ear hair cells. Science 284: 1837-1841.

Boord RL. 1969. The anatomy of the avian auditory system. Ann NY Acad Sci 167: 186-198.

Cafaro J, Lee GS, Stone JS. 2007. Atoh1 expression defines activated progenitors and differentiating hair cells during avian hair cell regeneration. Dev Dyn 236: 156-170.

Corwin JT, Cotanche DA. 1988. Regeneration of sensory hair cells after acoustic trauma. Science 240: 1772-1774.

Cotanche DA. 1987. Regeneration of hair cell stereociliary bundles in the chick cochlea following severe acoustic trauma. Hear Res 30: 181-195.

Cotanche DA, Henson MM, Henson OW Jr. 1992. Contractile proteins in the hyaline cells of the chicken cochlea. J Comp Neurol 324: 353-364.

Cotsarelis G, Sun TT, Lavker RM. 1990. Label-retaining cells reside in the bulge area of pilosebaceous unit: Implications for follicular stem cells, hair cycle, and skin carcinogenesis. Cell 61: 1329-1337.

Cox BC, Chai R, Lenoir A, Liu Z, Zhang L, Nguyen DH, Chalasani K, Steigelman KA, Fang J, Rubel EW, et al. 2014. Spontaneous hair cell regeneration in the neonatal mouse cochlea in vivo. Development 141: 816-829.

Dallos P, Billone MC, Durrant JD, Wang C, Raynor S. 1972. Cochlear inner and outer hair cells: Functional differences. Science 177: 356-358.

Desai TJ, Brownfield DG, Krasnow MA. 2014. Alveolar progenitor and stem cells in lung development, renewal and cancer. Nature 507: 190-194.

Dor Y, Brown J, Martinez OI, Melton DA. 2004. Adult pancreatic $\beta$-cells are formed by self-duplication rather than stem-cell differentiation. Nature 429: 41-46.

Drenckhahn D, Merte C, von During M, Smolders J, Klinke R. 1991. Actin, myosin and $\alpha$-actinin containing filament bundles in hyaline cells of the caiman cochlea. Hear Res 54: 29-38.

Durruthy-Durruthy R, Heller S. 2015. Applications for single cell trajectory analysis in inner ear development and regeneration. Cell Tissue Res 361: 49-57.

Ellwanger DC, Scheibinger M, Dumont RA, Barr-Gillespie PG, Heller S. 2018. Transcriptional dynamics of hair- 
bundle morphogenesis revealed with CellTrails. Cell Rep 23: 2901-2914.

Fischer FP, Miltz C, Singer I, Manley GA. 1992. Morphological gradients in the starling basilar papilla. J Morphol 213: 225-240.

Frisancho JC, Fritsma L, Raphael Y. 1997. Presynaptic terminals in hyaline cells of normal and overstimulated chick inner ears. J Neurocytol 26: 121-131.

Gnedeva K, Jacobo A, Salvi JD, Petelski AA, Hudspeth AJ. 2017. Elastic force restricts growth of the murine utricle. eLife 6: e25681.

Goodyear R, Richardson G. 1997. Pattern formation in the basilar papilla: Evidence for cell rearrangement. J Neurosci 17: 6289-6301.

Grompe M. 2012. Tissue stem cells: New tools and functional diversity. Cell Stem Cell 10: 685-689.

Hashino E, TinHan EK, Salvi RJ. 1995. Base-to-apex gradient of cell proliferation in the chick cochlea following kanamycin-induced hair cell loss. Hear Res 88: 156-168.

Hawkins JE Jr, Lurie MH. 1952. The ototoxicity of streptomycin. Ann Otol Rhinol Laryngol 61: 789-809.

Hawkins RD, Bashiardes S, Powder KE, Sajan SA, Bhonagiri V, Alvarado DM, Speck J, Warchol ME, Lovett M. 2007. Large scale gene expression profiles of regenerating inner ear sensory epithelia. PLoS ONE 2: e525.

Held H. 1926. Handbuch der normalen und pathologischen Physiologie mit Berücksichtigung der experimentellen Pharmakologie [Handbook of normal and pathological physiology with consideration of experimental pharmacol$o g y$ ]. Springer, Berlin.

Keppler C, Schermuly L, Klinke R. 1994. The course and morphology of efferent nerve fibres in the papilla basilaris of the pigeon (Columba livia). Hear Res 74: 259-264.

Ku YC, Renaud NA, Veile RA, Helms C, Voelker CC, Warchol ME, Lovett M. 2014. The transcriptome of utricle hair cell regeneration in the avian inner ear. J Neurosci 34: 3523-3535.

Li W, Wu J, Yang J, Sun S, Chai R, Chen ZY, Li H. 2015. Notch inhibition induces mitotically generated hair cells in mammalian cochleae via activating the Wnt pathway. Proc Natl Acad Sci 112: 166-171.

Lippe W, Rubel EW. 1983. Development of the place principle: Tonotopic organization. Science 219: 514-516.

Lippe WR, Zirpel L, Stone JS. 2002. Muscarinic receptors modulate intracellular $\mathrm{Ca}^{2+}$ concentration in hyaline cells of the chicken basilar papilla. J Comp Physiol A Neuroethol Sens Neural Behav Physiol 188: 381-395.

Lurie MH, Davis H, Hawkins JE. 1944. Acoustic trauma of the organ of Corti in the guinea pig. Laryngoscope 54: 375-386.

Manley GA. 1990. Peripheral hearing mechanisms in reptiles and birds. Springer, Berlin.

McLean WJ, Yin X, Lu L, Lenz DR, McLean D, Langer R, Karp JM, Edge ASB. 2017. Clonal expansion of Lgr5-positive cells from mammalian cochlea and high-purity generation of sensory hair cells. Cell Rep 18: 1917-1929.

Nagendran M, Riordan DP, Harbury PB, Desai TJ. 2018. Automated cell-type classification in intact tissues by single-cell molecular profiling. eLife 7: e30510.
Odinokova GV, Prokof eva LI. 1975. Innervation of posterior hyaline cells in the bird cochlea. Nauchnye Doki Vyss Shkoly Biol Nauki 6: 24-26.

Oesterle EC, Tsue TT, Rubel EW. 1997. Induction of cell proliferation in avian inner ear sensory epithelia by insulin-like growth factor-I and insulin. J Comp Neurol 380: 262-274.

Oesterle EC, Bhave SA, Coltrera MD. 2000. Basic fibroblast growth factor inhibits cell proliferation in cultured avian inner ear sensory epithelia. J Comp Neurol 424: 307-326.

Oshima K, Grimm CM, Corrales CE, Senn P, Martinez Monedero R, Geleoc GS, Edge A, Holt JR, Heller S. 2007. Differential distribution of stem cells in the auditory and vestibular organs of the inner ear. J Assoc Res Otolaryngol 8: 18-31.

Ouadah J. 2018. "Cellular and genetic dissection of pulmonary neuroendocrine stem cells and the initiation of small cell lung cancer." Dissertation, Stanford University, Stanford, CA.

Potten CS, Morris RJ. 1988. Epithelial stem cells in vivo. J Cell Sci Suppl 10: 45-62.

Raphael Y. 1992. Evidence for supporting cell mitosis in response to acoustic trauma in the avian inner ear. $\mathrm{J} \mathrm{Neu-}$ rocytol 21: 663-671.

Retzius G. 1884. Das Gehörorgan der Wirbelthiere [The hearing organ of vertebrates]. Samson and Wallin, Stockholm.

Robertson D, Johnstone BM. 1979. Aberrant tonotopic organization in the inner ear damaged by kanamycin. J Acoust Soc Am 66: 466-469.

Roberson DW, Alosi JA, Cotanche DA. 2004. Direct transdifferentiation gives rise to the earliest new hair cells in regenerating avian auditory epithelium. J Neurosci Res 78: 461-471.

Rosenhall U. 1971. Morphological patterns of the organ of Corti in birds. Arch Klin Exp Ohren Nasen Kehlkopfheilkd 200: 42-63.

Rubel EW, Ryals BM. 1982. Patterns of hair cell loss in chick basilar papilla after intense auditory stimulation. Exposure duration and survival time. Acta Otolaryngol 93: 3141.

Rubel EW, Furrer SA, Stone JS. 2013. A brief history of hair cell regeneration research and speculations on the future. Hear Res 297: 42-51.

Ryals BM, Rubel EW. 1988. Hair cell regeneration after acoustic trauma in adult Coturnix quail. Science 240: 1774-1776.

Scheibinger M, Ellwanger DC, Corrales CE, Stone JS, Heller S. 2018. Aminoglycoside damage and hair cell regeneration in the chicken utricle. J Assoc Res Otolaryngol 19: $17-$ 29

Shi F, Kempfle JS, Edge AS. 2012. Wnt-responsive Lgr5expressing stem cells are hair cell progenitors in the cochlea. J Neurosci 32: 9639-9648.

Shi F, Hu L, Edge AS. 2013. Generation of hair cells in neonatal mice by $\beta$-catenin overexpression in Lgr5-positive cochlear progenitors. Proc Natl Acad Sci 110: 1385113856.

Sinkkonen ST, Chai R, Jan TA, Hartman BH, Laske RD, Gahlen F, Sinkkonen W, Cheng AG, Oshima K, Heller S. 2011. Intrinsic regenerative potential of murine cochlear supporting cells. Sci Rep 1: 26. 
A.S. Janesick and S. Heller

Steyger PS, Burton M, Hawkins JR, Schuff NR, Baird RA 1997. Calbindin and parvalbumin are early markers of non-mitotically regenerating hair cells in the bullfrog vestibular otolith organs. Int J Dev Neurosci 15: 417-432.

Stone JS, Cotanche DA. 1994. Identification of the timing of $S$ phase and the patterns of cell proliferation during hair cell regeneration in the chick cochlea. J Comp Neurol 341: $50-67$.

Stone JS, Rubel EW. 2000. Temporal, spatial, and morphologic features of hair cell regeneration in the avian basilar papilla. J Comp Neurol 417: 1-16.

Takasaka T, Smith CA. 1971. The structure and innervation of the pigeon's basilar papilla. J Ultrastruct Res 35: 20-65.

Teta M, Rankin MM, Long SY, Stein GM, Kushner JA. 2007. Growth and regeneration of adult $\beta$ cells does not involve specialized progenitors. Dev Cell 12: 817-826.

Vinnikov Ya A, Osipova IV, Titova LK, Govardovskii VI. 1965. Electron microscopy of the organ of Corti in birds. Zh Obshch Biol 26: 138-150.

Wang F, Flanagan J, Su N, Wang LC, Bui S, Nielson A, Wu X, Vo HT, Ma XJ, Luo Y. 2012. RNAscope: A novel in situ RNA analysis platform for formalin-fixed, paraffin-embedded tissues. J Mol Diagn 14: 22-29.
Warchol ME, Stone J, Barton M, Ku J, Veile R, Daudet N Lovett M. 2017. ADAM10 and $\gamma$-secretase regulate sensory regeneration in the avian vestibular organs. Dev Biol 428: 39-51.

Warchol ME, Barton M, Kaur T, Lovett M. 2018. YAP1 signaling is activated by hair cell injury and is associated with regenerative proliferation in the avian inner ear. In 41st Annual Midwinter Meeting of the Association for Research in Otolaryngology, Poster PS 203. San Diego, CA, February 10-14.

White PM, Doetzlhofer A, Lee YS, Groves AK, Segil N. 2006 Mammalian cochlear supporting cells can divide and trans-differentiate into hair cells. Nature 441: 984-987.

White PM, Stone JS, Groves AK, Segil N. 2012. EGFR signaling is required for regenerative proliferation in the cochlea: Conservation in birds and mammals. Dev Biol 363: 191-200.

Wu J, Li W, Lin C, Chen Y, Cheng C, Sun S, Tang M, Chai R, Li H. 2016. Co-regulation of the Notch and Wnt signaling pathways promotes supporting cell proliferation and hair cell regeneration in mouse utricles. Sci Rep 6: 29418.

Yue Z, Jiang TX, Widelitz RB, Chuong CM. 2005. Mapping stem cell activities in the feather follicle. Nature 438: 1026-1029. 


\section{$\&_{\mathrm{CSH}}^{\infty} \&$ Cold Spring Harbor

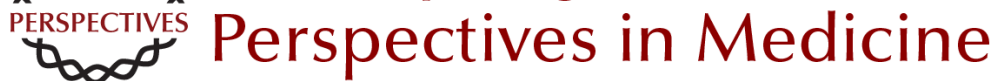

\section{Stem Cells and the Bird Cochlea-Where Is Everybody?}

Amanda S. Janesick and Stefan Heller

Cold Spring Harb Perspect Med 2019; doi: 10.1101/cshperspect.a033183 originally published online September 24, 2018

\section{Subject Collection Function and Dysfunction of the Cochlea}

Hidden Hearing Loss: A Disorder with Multiple Etiologies and Mechanisms

David C. Kohrman, Guoqiang Wan, Luis Cassinotti, et al.

Hair Cell Afferent Synapses: Function and Dysfunction

Stuart L. Johnson, Saaid Safieddine, Mirna Mustapha, et al.

Active Biomechanics of Sensory Hair Bundles Dolores Bozovic

The Tectorial Membrane: Mechanical Properties and Functions Jonathan B. Sellon, Roozbeh Ghaffari and Dennis M. Freeman

The Epidemiology of Deafness Abraham M. Sheffield and Richard J.H. Smith

Toward the Optical Cochlear Implant Tobias Dombrowski, Vladan Rankovic and Tobias Moser

Outer Hair Cells and Electromotility Jonathan Ashmore

Interactions between Macrophages and the Sensory Cells of the Inner Ear Mark E. Warchol
Development and Patterning of the Cochlea: From Convergent Extension to Planar Polarity Mireille Montcouquiol and Matthew W. Kelley

Hair-Bundle Links: Genetics as the Gateway to Function

Guy P. Richardson and Christine Petit

Aminoglycoside- and Cisplatin-Induced Ototoxicity: Mechanisms and Otoprotective Strategies

Corné J. Kros and Peter S. Steyger

Function and Dysfunction of TMC Channels in Inner Ear Hair Cells

David P. Corey, Nurunisa Akyuz and Jeffrey R. Holt

Cochlear Gene Therapy

Lawrence Lustig and Omar Akil

Age-Related Hearing Loss

Michael R. Bowl and Sally J. Dawson

Inner Ear Connexin Channels: Roles in Development and Maintenance of Cochlear Function Fabio Mammano

A Functional Perspective on the Evolution of the Cochlea Christine Köppl and Geoffrey A. Manley

For additional articles in this collection, see http://perspectivesinmedicine.cshlp.org/cgi/collection/ 